Janusz Maciaszek

Katedra Logiki i Metodologii Nauk

Uniwersytet Łódzki

januszm@uni.lodz.pl

\title{
TRZY TYPY MANIPULACJI Z PUNKTU WIDZENIA TEORII DZIALANIA
}

\begin{abstract}
ABSTRAKT
Manipulację można rozumieć jako nadużywanie wpływu na innych. Termin „nadużywanie” jest jednak na tyle niejasny, że nie w każdym przypadku możemy rozstrzygnąć czy faktycznie mamy do czynienia $\mathrm{z}$ nadużywaniem wpływu, czy też wpływ wywierany na innych jest dopuszczalny lub uzasadniony. W pracy wyróżnia się trzy typy działań polegających na wywieraniu wpływu na innych ludzi. Teoretyczną podstawę tego rozróżnienia stanowi teoria działania Donalda Davidsona, w szczególności zaś wprowadzonego przezeń pojęcia powodu działania oraz sylogizmu praktycznego. Pierwszy typ polega na modyfikowaniu względnie stałych przekonań, preferencji i wartości. Działania drugiego typu polegają na zmianie postaw żywionych $\mathrm{w}$ danym miejscu i czasie, np. wpływaniu na doraźne chęci i przekonania na temat sytuacji, w której znajduje się poddana tym działaniom osoba. W trzecim typie działań nie chodzi o modyfikację jakichkolwiek postaw (stałych lub doraźnych), lecz o skłonieniu danej osoby do zachowania akratycznego, tj. manifestującego słabość woli. Rozróżnienie to pozwala przynajmniej częściowo doprecyzować na czym polega nadużycie, które pozwala uznać działanie danego wyróżnionego typu za przejaw manipulacji.
\end{abstract}

\section{SŁOWA KLUCZOWE}

Działanie, intencja, manipulacja, postawa propozycjonalne, powód działania, przyczynowość, sprawca, sylogizm praktyczny, zamiar.

\section{UWAGI WSTĘPNE}

Jednym z problemów teorii manipulacji jest zdefiniowanie samego terminu „manipulacja”. Ze względu na wielość znaczeń tego terminu, z którymi można się spotkać w literaturze, punktem wyjścia niniejszych rozważań będzie podejście reprezentowane przez van Dijka w artykule Discourse and Manipu- 
lation [van Dijk 2006]. Przez manipulację rozumie on wywieranie i nadużywanie wpływu na innych:

(...) manipulacja implikuje działanie w formie nielegalnego wpływu (illegitimate influence) za pomocą środków dyskursywnych: manipulatorzy skłaniają innych, aby uwierzyli w coś lub czynili rzeczy, które leżą w interesie manipulatora i wbrew najlepszemu interesowi manipulowanego [tamże, s. 360].

Manipulacja w rozumieniu van Dijka realizuje się przede wszystkim poprzez „tekst i mowę” co nie wyklucza możliwości użycia innych środków: „obrazów, fotografii lub innych mediów" [tamże].

W słowach „aby uwierzyli w coś lub czynili rzeczy” mowa jest zarówno o postawach propozycjonalnych, w tym przypadku o przekonaniach, jak i o działaniach, co stanowi punkt wyjścia niniejszych rozważań. Działania ludzkie są z definicji intencjonalne ${ }^{1}$, co oznacza, mówiąc niezbyt precyzyjnie, że uwikłane są w pewne pragnienia, wartości, przekonania i preferencje, zaś brak tego uwikłania oznacza, że człowiek jedynie uczestniczymy w jakimś zdarzeniu. Modyfikacja postaw podmiotu niewątpliwie wpływa na modyfikację jego przyszłych działań. Dlatego też celem manipulatora jest przede wszystkim modyfikacja działań podejmowanych przez osoby manipulowane, zaś zmiana postaw propozycjonalnych stanowi środek, który do tego prowadzi. Jednym z podstawowych celów tego artykułu jest wyjaśnienie, na czym polega wspomniane uwikłanie postaw w ludzkie działania. Rozwiązanie Van Dijka nie wyjaśnia do końca problemu uwikłania postaw w działania, gdyż odwołuje się do niejasnego i przedteoretycznego pojęcia kontroli:

Manipulowanie ludźmi obejmuje manipulowanie ich umysłami, tj. przekonaniami ludzi, takimi jak wiedza, opinie i ideologie, które z kolei kontrolują ich działania [tamże, s. 365].

To, że postawy propozycjonalne w pewnym sensie kontrolują ludzkie działania jest oczywiste. Aby jednak lepiej zrozumieć wpływ manipulatora na działania manipulowanego poprzez modyfikację postaw propozycjonalnych należy dokładnie wyjaśnić owo pojęcie. Dlatego też w artykule tym zostanie zaproponowany pewien aparat teoretyczny, który pozwala opisać i analizować wpływ wszelkich zabiegów manipulacyjnych na działania osoby manipulowanej poprzez modyfikację jej postaw propozycjonalnych. W tym celu odwołuję się do przyczynowej teorii działania Donalda Davidsona, która - moim

\footnotetext{
${ }^{1}$ Zamiast terminu „intencjonalny” można użyć terminu „Zamierzony”. W tym konkretnym przypadku używam pierwszego terminu, gdyż nieco dalej zaproponuję pewną różnicę znaczeniową między tymi terminami.
} 
zdaniem - jest w stanie wyjaśnić wspomniane pojęcie kontroli przez odwołanie się do związku przyczynowego. Proponowane tu podejście jest raczej filozoficzne, nie zaś kognitywne lub psychologiczne. Nie chodzi tu zatem o badanie szczegółowych technik manipulacyjnych, ale raczej o odpowiedź na „transcendentalne” pytanie „Jak wpływanie na drugiego człowieka jest w ogóle możliwe?" Dodatkowo proponuje się pewną typologię zabiegów manipulacyjnych, która jest rezultatem przyjętych założeń. Jak się zdaje typologia ta jest dobrze egzemplifikowana przez wiele zabiegów manipulacyjnych, z którymi można się spotkać zarówno w życiu publicznym, jak i w marketingu.

Odróżnienie manipulacji od innych zabiegów kształtowania ludzkich postaw jest względne i ma raczej charakter ocenny. Ocena czy doszło do manipulacji może być inna z pozycji „manipulatora”, a inna z pozycji „manipulowanego". Przyczynowa teoria działania nie ogranicza się do zabiegów manipulacyjnych sensu stricto i pozwala analizować również wszelkie oddziaływania na ludzkie postawy i działania, nawet te neutralne lub nawet pozytywne z etycznego punktu widzenia. Dlatego też będę wprawdzie pisał o manipulacji, ale większość proponowanych rozstrzygnięć odnosi się również do oddziaływań niemanipulacyjnych. Można zatem uznać, że ograniczenie się do manipulacji ma jedynie charakter uproszczenia. Przedstawione tu przyczynowe podejście do kształtowania postaw i wpływania na działania ludzkie pozwala wyjaśnić nie tylko oddziaływania językowe, ale również oddziaływania za pomocą dowolnych środków pozajęzykowych, gdyż oddziaływanie za pomocą środków językowych jest tylko jednym $\mathrm{z}$ wielu możliwych oddziaływań przyczynowych podejmowanych przez manipulatorów.

Cel pracy jest czysto teoretyczny, jednak w celach ilustracyjnych odwołam się do kilku przykładów, głównie związanych z zabiegami reklamowymi oraz marketingowymi, które można - nieco żartobliwie - określić jako czyste przypadki manipulacji, gdyż skłaniają nas do działań, czyli zakupów, zazwyczaj wbrew naszemu ,najlepszemu interesowi"2. Co więcej przykłady z zakresu reklamy i marketingu dobrze ilustrują omawiane w tym artykule trzy typy manipulacji.

\footnotetext{
${ }^{2}$ Pomysł zastosowania teorii działania Davidsona do analizy manipulacji nasunął mi się podczas seminariów z moją doktorantką mgr Alicją Markiewicz, które przedstawiała mi różne rodzaje zabiegów marketingowych i reklamowych. Za przykłady te jestem jej bardzo wdzięczny.
} 


\section{ZDARZENIA I PRAWA PRZYCZYNOWE}

Zanim przejdziemy do omówienia kategorii działania w filozofii Davidsona należy poświęcić nieco uwagi ogólnym założeniom jego filozofii. Donald Davidson był jednym z nielicznych współczesnych filozofów, który miał ambicje stworzenia całościowego systemu filozoficznego, w którym poczesne miejsce zajmowała filozofia języka i filozofia działania. Fundament ontologiczny jego filozofii stanowią dwa niedefiniowalne pojęcia: indywidualnych obiektów oraz zdarzeń. Między zdarzeniami, które można ogólnie określić jako zmiany, w których uczestniczą indywidualne obiekty, mogą zachodzić relacje przyczynowe ${ }^{3}$. Szczególnym rodzajem zdarzeń są działania ludzkie. Zdania opisujące związki przyczynowe między pojedynczymi zdarzeniami mają postać „Zdarzenie $A$ jest przyczyną zdarzenia $B$ ” lub „Zdarzenie $A$ spowodowało zdarzenie $B$ ".

Davidson uznawał zasadę domknięcia przyczynowego, która głosi, że każde zdarzenie ma przyczynę. Jeżeli przyjmiemy, że zmiana postaw propozycjonalnych jest zdarzeniem (bo jest zmianą zachodzącą $\mathrm{w}$ indywidualnym obiekcie), to zgodnie z zasadą domknięcia przyczynowego zmiana taka ma również swoją przyczynę. W szczególności przyczyną tej zmiany może być działanie manipulatora, które również jest pewnym zdarzeniem. W związku z tym szczegółowego wyjaśnienia wymaga kilka problemów, którymi zajmę się w kolejnych paragrafach artykułu:

1) Co to jest działanie i czym się różni od zdarzeń, które działaniami nie są?

2) Co to jest zdarzenie psychiczne i czy zdarzenie psychiczne jest działaniem?

3) Czy zmiany postaw propozycjonalnych manipulowanego są zdarzeniami psychicznymi i działaniami?

4) Czy zmiana postaw manipulowanego może być przyczyną jego dalszych działań?

5) Czy działanie manipulatora może być przyczyną jakiś działań manipulowanego bez zmiany jego postaw propozycjonalnych?

Zanim odpowiemy na te pytania wyjaśnijmy pewien problem natury filozoficznej o praktycznych konsekwencjach. Zasada domknięcia przyczynowego bywa niekiedy błędnie utożsamiana $\mathrm{z}$ tezą determinizmu. Teza determinizmu (w ujęciu Davidsona) głosi, że dla dwóch dowolnych zdarzeń, z których pierwsze jest przyczyną drugiego, istnieje (nomologiczne) prawo przyczyno-

\footnotetext{
${ }^{3} \mathrm{~W}$ szczególności zdarzeniem może być po prostu zmiana zachodząca $\mathrm{w}$ indywidualnym przedmiocie, np. w układzie nerwowym człowieka.
} 
we, które pozwala przewidzieć skutek, o ile zaszła przyczyna. Przy takim sformułowaniu tej tezy, Davidson jest niewątpliwie zwolennikiem tezy determinizmu. Czy oznacza to, że zdaniem Davidson możliwe byłyby ścisłe „prawa manipulacji”, równie niezawodne jak prawa fizyki? Pomimo uznania tezy determinizmu, Davidson odpowiedziałby na to pytanie negatywnie.

Aby to wyjaśnić zauważmy, że prawa przyczynowe formułowane są zawsze w języku, zaś relacja przyczynowa zachodzi między zdarzeniami obiektywnie, tj. niezależnie od tego, w jakim języku je opiszemy. Aby zastosować prawo przyczynowe do zdarzeń będących przyczyną i skutkiem musimy umieć opisać te zdarzenia w języku, w którym sformułowane jest to prawo. Bardzo często zdania opisujące związki przyczynowe między zdarzeniami formułowane są w języku, który uniemożliwia sformułowanie odpowiedniego prawa, co widać wyraźnie w sugestywnym przykładzie:

Załóżmy, że huragan opisany na piątej stronie wtorkowego Timesa spowodował katastrofę opisaną na stronie trzynastej środowej Tribune. Wówczas zdarzenie opisane na piątej stronie Timesa było przyczyną zdarzenia opisanego na stronie trzynastej środowej Tribune. Czy możemy szukać praw, które łączą tego rodzaju zdarzenia? [Davidson 1980(1963), s. 17]

W tym miejscu ktoś mógłby zgłosić następujące zastrzeżenie: aby móc przewidywać skutki zdarzeń przy dowolnych ich opisach wystarczy przełożyć owe opisy na język, w którym sformułowano właściwe prawo przyczynowe. Gdyby faktycznie było to możliwe, to mielibyśmy do czynienia (przy założeniu pewnego poziomu wiedzy naukowej) z pełną możliwością przewidywania skutków wszelkich zdarzeń i działań. Istnienie takiej możliwości wzbudza oczywiste opory w przypadku ludzkich działań, gdyż pozwalałaby między innymi na formułowanie całkowicie skutecznych, bo opartych na nomologicznych prawach, reguł manipulacji ludźmi, zaś brak takich praw w chwili obecnej należałoby złożyć jedynie na karb niedorozwoju badań teoretycznych, które nie pozwalają w tej chwili na ich sformułowanie. Jednak możliwość taka wydaje się nie do pogodzenia z przekonaniem, że jesteśmy wolni i nawet jeśli większość ludzi wykazuje tendencję do podejmowania pewnego typu działań lub zmiany przekonań na skutek określonego typu przyczyn (np. zabiegów manipulacyjnych), to zawsze mamy możliwość nie podjęcia owych działań lub podjęcia działań alternatywnych i nigdy nie udaje się zmienić przekonań wszystkich. Oznacza to, że nawet najskuteczniejsze z możliwych metod manipulacji nie mogą z natury charakteryzować się stuprocentową skutecznością. To ostatnie stanowisko podzieliłby również Davidson, gdyż jest ono zgodne z zaproponowanym przez niego oryginalnym rozwiązaniem problemu 
wolnej woli. Rozwiązanie to nie stoi w sprzeczności ani z zasadą domknięcia przyczynowego, ani z tezą determinizmu.

Każdy człowiek przeżywa nieustannie zdarzenia psychiczne (akty psychiczne). Każdy czegoś pragnie, coś sobie przypomina, coś dostrzega, w coś wątpi itp ${ }^{4}$. Davidson stał na stanowisku identyczności zdarzeń psychicznych i zdarzeń fizycznych. Oznacza to, że każdy akt psychiczny jest jednocześnie zdarzeniem fizycznym zachodzącym w układzie nerwowym. A zatem nachodząca nas chęć zjedzenia reklamowanego batonika jest zdarzeniem, które może być opisane również jako pobudzenie pewnej grupy neuronów. Jednocześnie Davidson stanowczo twierdzi, że możemy wprawdzie utożsamić konkretne zdarzenie psychiczne z konkretnym zdarzeniem fizycznym, ale nie możemy utożsamić żadnej klasy zdarzeń psychicznych z żadną klasa zdarzeń fizycznych, co oznacza nieprzekładalność predykatów psychologicznych na predykaty fizykalne ${ }^{5}$.

Wedle Davidsona w języku psychologii popularnej (tj. w języku postaw propozycjonalnych) nie da się formułować ścisłych praw przyczynowych, lecz da się je formułować w języku fizykalnym. Jednocześnie nieprzekładalność predykatów psychologicznych na fizykalne powoduje, że zdarzeń opisanych jako psychiczne nie da się podciągnąć pod ścisłe prawa. W konsekwencji zdarzenia psychiczne są wprawdzie zdarzeniami fizycznymi (monizm), ale są nieprzewidywalne, tj. anomalne, zaś wolność rozumiana jest jako anomalność zdarzeń psychicznych. Oczywiście takie rozumienie wolności prawdopodobnie nie zaspokaja wszystkich naszych intuicji oraz oczekiwań związanych $\mathrm{z}$ tym pojęciem, ale $\mathrm{z}$ punktu widzenia celów tego artykułu jest całkowicie wystarczające i kontekście tematyki związanej z manipulacją posiada niewątpliwie optymistyczny wydźwięk. Żaden manipulator, specjalista od marketingu, propagandzista lub specjalista od prania mózgów nie może dysponować technikami, które pozwolą mu całkowicie zawładnąć pragnieniami i wolą wszystkich ludzi, co nie przeczy oczywistemu faktowi, że pewne zabiegi manipulacyjne w przypadku wielu osób mogą być niezwykle skuteczne. Uzasadnienie tezy monizmu anomalnego wykracza poza cele tego artykułu. W tym miejscu warto jednak zwrócić uwagę na obecny w uzasadnieniu tej tezy holistyczny aspekt postaw propozycjonalnych, które tworzą złożoną sieć. Stworzenie modelu owej sieci obejmującego zależności między różnymi rodzajami postaw (przekonań, preferencji, pragnień, uprzedzeń itp.) pozwoli-

\footnotetext{
${ }^{4}$ Mowa w tym miejscu o aktach psychicznych, nie zaś o dyspozycjach aktualizowanych przez te akty. Postawy propozycjonalne są dyspozycjami do aktów psychicznych.

${ }^{5}$ Mamy tu zatem do czynienia $\mathrm{z}$ redukcją ontologiczną zdarzeń psychicznych do zdarzeń fizycznych, lecz nie z redukcją pojęciową.
} 
łoby na dokładna analizę poszczególnych technik manipulacyjnych. Zadanie to wykracza jednak poza cele tego artykułu. Warto jednak zauważyć, że w skład sieci postaw wchodzą elementy stabilne (niektóre przekonania, wartości i preferencje) oraz elementy zmienne, które zależą od sytuacji, w której znajduje się podmiot (przelotne pragnienia lub przekonania na temat aktualnego stanu środowiska).

Wprawdzie metafora sieci pochodzi od Davidsona, ale widać wyraźnie, że inspiracje dla niej stanowi wprowadzona przez Quine'a metafora pola sił, która opisuje teorię naukową ${ }^{6}$, podkreślając zarazem jej holistyczny aspekt. $\mathrm{Z}$ tego punktu widzenia teorię naukową można określić jako szczególną sieć, która ogranicza się do zawartości przekonań, które można niezbyt precyzyjnie określić jako naukowe. W „centrum” teorii znajdują się, obok praw logiki i matematyki, również prawa przyczynowe. Jednak między tak rozumianą teorią w sensie Quine'a a davidsonowską siecią postaw zachodzi istotna różnica. Jest to różnica języka. Postawy propozycjonalne opisywane są w języku psychologicznym, co uniemożliwia idealizację. Zaś to właśnie idealizacja pozwala na formułowanie praw przyczynowych ${ }^{7}$. W konsekwencji praw przyczynowych, zdaniem Davidsona, nie ma.

\section{DZIAŁANIA ORAZ ICH POWODY}

Do tej pory była mowa o zdarzeniach psychicznych i ich nieprzewidywalności na podstawie ścisłych praw (anomalizm). W tym paragrafie powiążę zdarzenia psychiczne z działaniami. Okaże się wówczas jasne dlaczego ludzkie działania nie podpadają, przy pewnym ich opisie, pod ścisłe prawa przyczynowe.

Wiemy już, że działania są szczególnego rodzaju zdarzeniami. W artykule Actions, Reasons, and Causes [1963] Davidson definiuje działanie poprzez odwołanie się do jego powodu (reason) działania. Przez powód konkretnego działania rozumie on następującą parę:

(a) pewne przed-nastawienie (pro-attitude) do działań pewnego typu, (b) wierzenia (lub wiedzenia, percypowania, zauważania, pamiętania), że to właśnie działanie jest tego typu [Davidson 1980(1963), s. 4].

\footnotetext{
${ }^{6}$ Chodzi tu oczywiście o teorie fizyczne.

${ }^{7} \mathrm{Na}$ poziomie języka idealizacja polega na pomijaniu $\mathrm{w}$ opisie zdarzenia jego kontekstu, dlatego też prawa fizyki, np. prawa Newtona, są bardzo proste. W przypadku języka psychologii to właśnie kontekst najbardziej nas interesuje. W rezultacie ewentualne prawa psychologii byłyby, w przeciwieństwie do praw fizyki, nieskończenie złożone.
} 
Do (a) Davidson włącza pragnienia, chęci, popędy, poglądy moralne, zasady estetyczne, umowy społeczne oraz wszelkie cele i wartości „o ile mogą być one interpretowane jako postawy sprawcy ${ }^{8}$ skierowane na działania pewnego typu" [tamże]. Przed-nastawienie wyraża zatem pożądany przez sprawcę cel. Określony cel można usiłować osiągnąć podejmując bardzo różne działania, które różnią się rodzajem podjętych środków. Drugi element pary odpowiada zatem środkom służącym do osiągnięcia celu, a dokładniej odpowiada przekonaniom sprawcy na ten temat. Przedstawione tu podejście do powodów działania wyraża uwikłanie działania w sieć postaw propozycjonalnych, czego wyrazem jest złożoność opisu powodu działania oraz możliwość podania wielu (prawdziwych) powodów tego samego działania.

Davidson stawia kontrowersyjną i szeroko dyskutowaną tezę głoszącą, że powód działania jest jego przyczyną. W tym momencie napotykamy oczywiście na spory kłopot, gdyż w poprzednim paragrafie była mowa, że przyczynami mogą być jedynie zdarzenia, zaś powód działania został zdefiniowany w kategoriach postaw, czyli dyspozycji do zdarzeń mentalnych. Na taki zarzut Davidson odpowiada, że powodem działania jest faktycznie jakieś zdarzenie mentalne, które jednak trudno nam opisać w sposób nietrywialny, tj. jakoś inaczej niż byciem aktualizacją pewnych postaw. Dlatego też zdarzenia te opisujemy za pomocą pary postaw, którą (łącznie) owo zdarzenie w aktualizuje. Podobnie bywa w przypadku opisów przyczyn zdarzeń typowo fizycznych. Nieznane bliżej przyczyny często opisujemy za pomocą predykatów dyspozycyjnych, np. zarwanie się mostu możemy opisać jako skutek osłabionej konstrukcji, chociaż faktycznie przyczyną jest jakieś zdarzenie, które miało miejsce w owej konstrukcji.

Podanie powodu pełni niewątpliwie funkcję wyjaśniającą, czyli racjonalizuje $^{9}$ działanie. W praktyce prawie nigdy nie podajemy explicite pełnego powodu działania, szczególnie gdy cele lub środki są oczywiste i znane. Ponadto podanie pełnego powodu może natrafić na poważne trudności językowe i przybrać niezręczna formę. Aby to zilustrować rozważmy następujący przykład. Na pytanie sędziego dlaczego sprawca ukradł samochód wystarcza skrócona odpowiedź „Bo chciałem zaimponować kolegom”, w której podaje się jedynie przed-nastawienie do działań pewnego typu (chęci imponowania kolegom). Stwierdzenia, że sprawca uważał, że kradzież samochodu jest aktem zaimponowania kolegom jest tutaj zbędne ${ }^{10}$. W pełnej

\footnotetext{
${ }^{8}$ Angielski termin agent thumaczę konsekwentnie za Kotarbińskim jako „sprawca”.

${ }^{9}$ Bo podaje powód, czyli rację działania (reason).

${ }^{10}$ Oczywiście trywialna, a nawet tautologiczna odpowiedź: „Bo chciałem go ukraść” byłaby zdecydowanie nie na miejscu. Byłby to jednak prawdziwy opis powodu działania.
} 
wersji powód miałby postać następującą: „Chciałem zaimponować kolegom i uważałem, że kradzież tego samochodu będzie zaimponowaniem kolegom”. Nie ma tutaj znaczenia czy koledzy byli świadkami kradzieży, czy też mieli się o niej dowiedzieć później, gdyż „zaimponowanie kolegom” oznacza działanie, którego skutkiem bliższym lub dalszym ma być wzbudzenie uczucie podziwu dla sprawcy. Podobnie zabicie kogoś oznacza działanie, którego skutkiem (natychmiastowym lub następującym za jakiś czas) jest śmierć ofiary. Dlatego też na pytanie o powód wsypania trucizny do czyjeś kawy sprawca może odpowiadać w zależności od okoliczności na wiele sposobów. Gdy śmierć ofiary faktycznie nastąpiła, należałoby podać powód nietrywialny, np. „Bo chciałem odziedziczyć spadek” (przed-nastawienie) lub „Bo myślałem, że to słodzik" (przekonanie). W pierwszym przypadku natrafiamy na pewną trudność językową, gdyż można mieć wątpliwości czy dziedziczenie spadku jest w ogóle działaniem (spadek można odziedziczyć nawet nie wiedząc o tym). Być może należy to rozumieć jako zwrot eliptyczny zastępujący „zapewnienie sobie dziedziczenia spadku”. Wówczas pełny powód miałby postać „Bo chciałem zapewnić sobie odziedziczenie spadku i uważałem, że wsypanie trucizny jest działaniem tego typu, tj. zapewnieniem sobie o dziedziczenia spadku". W drugim przypadku pełny powód mógłby przybrać postać następującą: „Bo chciałem posłodzić kawę gościowi i myślałem, że wsypanie białego proszku jest działaniem tego typu, tj. posłodzeniem kawy”.

Zarówno powód, jaki i każde zdarzenie może być opisane na wiele sposobów. Dotyczy to również działań, które mogą być opisane w kategoriach powodów ( $\mathrm{tj}$. jako działanie intencjonalne, tj. powodowane intencją zrobienia czegoś lub osiągnięcia jakiegoś celu), w kategoriach skutków (zrobienie czegoś, bez względu na to czy zamierzony cel działania został osiągnięty) oraz wielu innych (np. jako ruchy ciała sprawcy). Działanie z ostatniego przykładu może być bowiem opisane jako działanie, którego celem było posłodzenia kawy, jako zabicie tego, kto ją wypił lub jako specyficzny ruch ręki sprawcy wsypującej do kawy truciznę lub biały proszek ${ }^{11}$. Istnienie opisu intencjonalnego danego zdarzenia, tj. opisu w kategoriach powodu, pozwala uznać zdarzenie za działanie. A zatem działanie $\mathrm{z}$ definicji jest zdarzeniem intencjonalnym, tj. posiadającym powód.

Działanie, jak widać na podanym przykładzie, nie zawsze pozwala osiągnąć pożądane skutki, co znajduje niekiedy odbicie w jego opisie. Co więcej, niekiedy możemy mieć wątpliwości czy jesteśmy świadkami czyjegoś działania, czy też zdarzenia, w którym on uczestniczy, np. potknięcie się. Jeśli jednak przypiszemy temu zdarzeniu powód, uznamy tym samym, że jest to

\footnotetext{
${ }^{11}$ Zauważmy, że są to dwa różne opisy.
} 
zdarzenie intencjonalne czyli działanie. A zatem z definicji każdy sprawca działa intencjonalnie. Nie oznacza to jednak, że za każdym razem miał zamiar zrobić to, co jest skutkiem jego działania. Innymi słowy nie każde działanie musi być zamierzone ${ }^{12}$.

Nieco wcześniej była mowa o tym, że powodem działania jest zawsze jakieś zdarzenie mentalne. Zdarzenia takie wymykają się nietrywialnemu opisowi w kategoriach psychologicznych - można je określać jedynie ogólnikowo jako jakiś wewnętrzny impuls, który nas popchnął do działania. Racjonalizacja działania, czyli podanie jego powodu, ma postać opisu postaw, które ów impuls miał zaktualizować. To samo działanie można jednak racjonalizować na różne sposoby, tj. można podawać różne opisy powodu działania. Może to być rezultatem nieszczerości sprawcy, który pragnąc uniknąć odpowiedzialności podaje raz po raz odmienne powody czynu, który popełnił. Jednak nawet jeśli założymy szczerość, temu samemu działaniu można i tak przyporządkować wiele powodów. W niektórych przypadkach zachodzą między ich opisami związki logiczne, np. chęć zabicia $x$-a wynika $\mathrm{z}$ chęci jego otrucia. Są jednak przypadki, gdy wahamy się między kilkoma powodami, np. czy powodem otrucia ciężko chorego krewnego była chęć zaoszczędzenia mu cierpień, czy też pragnienie odziedziczenia spadku. W wielu przypadkach nie potrafimy podać jasnych powodów własnych działań, chociaż wiemy, że jakieś powody musiały istnieć. Podane tu przykłady potwierdzają tezę, że relacji przyczynowej między powodem a działaniem nie da się opisać za pomocą żadnego prawa przyczynowego.

Termin „powód” jest jednym z dwóch podstawowych odpowiedników angielskiego terminu reason. W jednym ze znaczeń oznacza on powód lub rację, a w drugim - rozum. Kiedy Davidson mówi, że każde działanie jest racjonalne, wówczas ma na myśli pierwsze ze znaczeń tego terminu i oznacza to jedynie, że działanie ma powód. A zatem każde działanie $z$ definicji jest nie tylko intencjonalne, ale jest również racjonalne we wspomnianym wyżej sensie. Davidson używa jednak terminu ,racjonalny” również w sensie odwołującym się do drugiego z podanych znaczeń. W tym sensie nie każde działanie musi być racjonalne, przy czym termin „racjonalny” ma tutaj wyraźnie wartościujący charakter. Oczywiście nie da się wymienić wszystkich przejawów nieracjonalności działań $\mathrm{w}$ drugim sensie. Można jednak podać kilka przykładów. Działanie określimy niekiedy jako nieracjonalne, gdy pragniemy osiągnąć cel, który będzie dla nas niekorzystny (w tym sensie, że

\footnotetext{
12 Odróżnienie między działaniem intencjonalnym (każde działanie jest takie z definicji) a działaniem zamierzonym nie jest możliwe na gruncie języka angielskiego. Wprowadziłem je po to, aby uniknąć pewnych niezręczności, które można spotkać w tekstach Davidsona.
} 
spowoduje niepożądane skutki), bez względu na to czy jesteśmy w stanie to przewidzieć, czy też nie. W tym przypadku nieracjonalność polega zazwyczaj na niezdolności do przewidywania skutków działań. Może to dotyczyć przednastawień (intencji) do działania lub niewłaściwego doboru środków, które nie gwarantują osiągnięcia celu. Nieracjonalność w drugim $\mathrm{z}$ wymienionych sensów dotyczy zatem oceny postaw żywionych przez sprawcę.

Zabiegi manipulacyjne mogą skutkować modyfikacją postaw manipulowanego. Zmiana postaw jest niewątpliwie zdarzeniem zachodzącym w podmiocie (zgodnie z poglądami Davidsona w jego układzie nerwowym), chociaż $\mathrm{z}$ pewnością nie jest działaniem ani manipulatora, ani działaniem manipulowanego. Nie jest również zdarzeniem mentalnym, chociaż uświadomienie sobie zmiany postaw propozycjonalnych jest niewątpliwie zdarzeniem mentalnym. Zmiana postaw nie jest zdziałaniem manipulatora, gdyż jest skutkiem jego działania. $Z$ tego samego powodu nie jest działaniem manipulowanego, gdyż gdyby była jego działaniem, to musiałaby mieć swoje powody opisane $\mathrm{w}$ kategoriach jego postaw propozycjonalnych ${ }^{13}$. Zmiana postaw manipulowanego może być natomiast przyczyną powodów jego działań. Działania manipulowanego sprawcy mogą być zatem dalszymi skutkami działań manipulatora. $\mathrm{Z}$ manipulacją w sensie van Dijka mamy zaś do czynienia, gdy działania manipulowanego sprawcy są nieracjonalne $\mathrm{w}$ drugim $\mathrm{z}$ wymienionych znaczeń tego terminu, tj. działaniami, których skutki są dla manipulowanego niekorzystne, a on sam tego nie dostrzega ${ }^{14}$.

\section{DWA TYPY MANIPULACJI A SYLOGIZM PRAKTYCZNY}

Pojęcie działania obejmuje u Davidsona nie tylko te intencjonalne zdarzenia, które można opisać również jako ruchy ciała - wsypywanie trucizny do kawy, naciśnięcie na spust pistoletu, celowe potykanie się o dywan, pisanie, mówienie lub przygotowywanie materiałów reklamowych. W zakres kategorii działania wchodzą również niektóre zdarzenia mentalne, których nie da się opisać jako „zewnętrznych” ruchów ciała: nóg, dłoni, czy też narządów mowy. Do takich zdarzeń mentalnych zalicza się przeprowadzanie obliczeń, rozumowanie lub formowanie zamiarów. Wymienione zdarzenia mentalne muszą mieć swoje powody, które również są zdarzeniami mentalnymi, np. obliczam

\footnotetext{
${ }^{13} \mathrm{~W}$ tym miejscu nie będę rozstrzygał czy w pewnych przypadkach zmiana postaw (poglądów) podmiotu nie może być w pewnych przypadkach jego działaniem. W takim przypadku podmiot nie byłby jednak, przynajmniej bezpośrednio, manipulowany.

${ }^{14}$ Nie likwiduje to możliwych kontrowersji co do tego co jest, a co nie korzystne i kto ma prawo to oceniać.
} 
sumę miesięcznych wydatków, gdyż chcę się dowiedzieć czy jestem rozrzutny i uważam, że obliczenie sumy miesięcznych wydatków jest działaniem tego typu, tj. dowiedzeniem się czy jestem rozrzutny. Jak pamiętamy każde zdarzenie mentalne jest również zdarzeniem fizycznym zachodzącym w układzie nerwowym, a zatem można je opisać również jako pewnego rodzaju „wewnętrzny ruch ciała".

Problem, na który natrafiamy dotyczy kryterium wyróżnienia działań mentalnych spośród ogółu zdarzeń mentalnych. W artykule Agency [1971] Davidson uzasadnia tezę, że powody wszelkich działań, które to powody można utożsamić z bezpośrednimi przyczynami owych działań, same działaniami nie są. Nic nie stoi jednak na przeszkodzie, aby uznać, że wśród dalszych przyczyn naszych działań znajdowały się zarówno nasze własne wcześniejsze działania (również działania mentalne), jak i działania innych, np. manipulatorów. Manipulator może bowiem przyczynowo oddziaływać na nasze postawy, których aktualizacje są powodami naszych działań.

Dwa typy działań manipulacyjnych, które wyróżniam w tym paragrafie można określić odwołując się bezpośrednio do zmian w owych postawach. Aby jednak oddzielić wyróżnione typy od typu trzeciego, który wprowadzę w paragrafie następnym, przyjrzymy się obecnie działaniu polegającemu na formowaniu zamiaru działania. Drugi powód odwołania się do formowania zamiarów działania jest nieco odmiennej natury. Manipulator odnosi pewien rodzaj sukcesu również wtedy, gdy manipulowany formuje zamiar, lecz nie może go zrealizować $\mathrm{z}$ powodów od siebie niezależnych, np., gdy klient zachęcony reklamą ma zamiar zakupić dany produkt, lecz nie może znaleźć go w sklepach.

Z działaniem polegającym na formowaniu zamiaru mamy do czynienia bardzo często, począwszy od powzięcia zamiaru poślubienia kogoś lub powzięcia zamiaru napisania rozprawy doktorskiej, aż do sformułowania listy zakupów. Rzecz jasna działanie to nie zawsze przybiera tak wyrazistą i w pełni uświadomioną postać. Formowanie zamiaru podjęcia działania przybiera postać tzw. sylogizmu praktycznego, który wedle Davidsona polega na wyciąganiu wniosku postaci: „Działanie $A$ jest pożądane $w$ świetle tego o czym jestem przekonany o najbliższej przyszłości” [Davidson 1980(1978), s. 99]. Oczywiście sprawca racjonalny, w trzecim sensie tego słowa, który doprecyzuję w następnym paragrafie, realizuje działania, które ma zamiar podjąć, o ile na przeszkodzie nie staną niezależne od niego przeszkody. Zrealizowane działanie ma swój powód, który jest jednak różny od działania polegającego na formowaniu zamiaru tego działania. Dlatego też w dalszym ciągu nie będę staranie odróżniał powodów działania, od zamiarów podjęcia owych działań. 
Nieco wcześniej była mowa o tym, że postawy propozycjonalne tworzą pewną złożoną sieć. Sieć ta ulega stałym przekształceniom - dotyczy to szczególnie postaw (preferencji, chęci i przekonań) doraźnych, uzależnionych od sytuacji, środowiska i samopoczucia. Istnieją jednak postawy trwałe, które $\mathrm{z}$ trudem, jeśli w ogóle, ulegają zmianom. Między jednymi a drugimi nie ma jednak wyraźnej granicy. W ramach sieci mogą wystąpić postawy pozornie przeciwstawne, np. mogę lubić słodycze, ale czuć się zobowiązanym do powstrzymywania się od ich jedzenia ze względów zdrowotnych. Ze względu na holistyczny aspekt postaw propozycjonalnych, obu postawom musi towarzyszyć cały szereg innych postaw obejmujących również wiedzę na temat tego, że słodycze zawierają cukier, że cukier szkodzi na zęby, jego nadmiar sprzyja cukrzycy, ale zawarta w słodyczach czekolada jest cennym źródłem zdrowego magnezu itp. Formowanie zamiaru zjedzenia (lub powstrzymania się od zjedzenia) ${ }^{15}$ leżącego przede mną batonika przybiera postać rozumowania, w którym za przesłanki przyjmuje się nasze uświadomione postawy oraz całą wiedzę obejmującą również przekonania na temat okoliczności zewnętrznych, samopoczucia aktualnego stanu zdrowia itp. Wniosek, do którego dochodzimy w rezultacie zastosowania sylogizmu praktycznego $^{16}$, Davidson nazywa osądem warunkowym (conditional judgement) lub osądem prima facie. Upraszczając nieco sprawę będę go dalej nazywał zamiarem warunkowym.

$\mathrm{Na}$ formowane przez nas zamiary warunkowe mają niewątpliwie wpływ informacje i oceny, które do nas docierają. Część z tych informacji podawana jest w dobrej wierze, część jednak może mieć na celu jedynie spowodowanie, abyśmy podjęli działania, które realizują jedynie interesy tych, którzy nam owe informacje podają. Sprowadzają się one do modyfikowania naszych postaw propozycjonalnych przez zmianę naszych wartości, preferencji i przekonań, np. kreowanie mody na anorektyczny wygląd wraz z promowaniem lekceważenia dla przestrzegania diety może mieć na celu, wraz z dostarczeniem informacji (często mijających się z prawdą) o działaniu środków odchudzających, skłonienie nas do zakupu tych specyfików.

Oczywiście łatwiej jest manipulować doraźnymi przekonaniami sprawcy niż jego w miarę stałymi przekonaniami, wartościami i preferencjami, chociaż i w takim przypadku manipulowanie jest możliwe. W szczególnym przypadku mamy wówczas do czynienia $\mathrm{z}$ tzw. praniem mózgu. Jest to długotrwały

\footnotetext{
${ }^{15}$ Nasze zamiary często zależą od owych doraźnych i zmiennych postaw. Osoba chora na cukrzycę zazwyczaj powstrzymuje się od jedzenia słodyczy, jednak w przypadku spadku poziomu cukru we krwi formuje zamiar zjedzenia czegoś słodkiego.

${ }^{16}$ Nie ma tu mowy, rzecz jasna, o wynikaniu logicznym.
} 
proces, w którym stosuje się wiele zabiegów manipulacyjnych skutkujących zmianą ugruntowanych przekonań, preferencji i wartości. $Z$ technik tych korzystają na przykład organizacje terrorystyczne o wyrazistym profilu ideologicznym lub religijnym. Nie zawsze jednak modyfikowanie podstawowych i w miarę stabilnych postaw propozycjonalnych jest domeną manipulacji ideologicznej. Spotkać je można również w kampaniach reklamowych, których celem jest nie tyle promowanie określonych produktów, co tworzenie tzw. wizerunku firmy. W kampaniach tych modyfikuje się $\mathrm{w}$ miarę stałe wartości i preferencje potencjalnych klientów w sposób pożądany z punktu widzenia zlecającego je koncernu ${ }^{17}$. Ich celem jest to, aby w konkretnych okolicznościach, np. podczas zakupów, gdy dostępne są artykuły różnych producentów, klient formułował pożądany przez danego producenta zamiar względny, którym preferuje się zakup jego produktu. W kampaniach tego typu pomija się zatem sugerowanie doraźnych przekonań, na rzecz budowania postaw stałych i stabilnych ${ }^{18}$. Na modyfikacji stałych postaw manipulowanego polega zatem pierwszy typ manipulacji. Manipulacja tego typu, często spotykana w złożonych kampaniach reklamowych i kampaniach politycznych $^{19}$, ukierunkowana jest również na modyfikację wielu względnie stałych, lecz współzależnych preferencji, chęci, wartości oraz przekonań ${ }^{20}$.

Drugi typ manipulacji polega na takim oddziaływaniu na sprawcę, aby zmodyfikować jego doraźne postawy i przekonania. Formułując zamiar względny uwzględniamy bowiem również okoliczności znane nam w momencie przeprowadzania rozumowania praktycznego. Oczywiście w przypadku zamiarów dotyczących działania w odległej przyszłości znane nam okoliczności mogą ulec zmianie, co może prowadzić w konsekwencji do zmiany zamiaru $^{21}$. Nawet jeśli układ naszych postaw propozycjonalnych jest w miarę

\footnotetext{
${ }^{17}$ Przykładem teorii opisującej tego typu zabiegi jest teoria metafory głębokiej [por. Zaltaman and Zaltman 2008]. Lektura tej pracy pokazuje jednocześnie, że wszelkie modyfikacje postaw propozycjonalnych muszą respektować pewne najgłębsze schematy wyobrażeniowe, zwane przez autorów metaforami głębokimi.

${ }^{18}$ Jedną z technik tego typu jest tzw. marketing narracyjny, w którym przekazuje się pozytywny przekaz o firmie nie reklamując konkretnych produktów. Na ten zabieg kształtowania postaw zwróciła moja uwagę pani Alicja Markiewicz, za co jestem wdzięczny.

${ }^{19}$ Proces modyfikowania postaw względnie stabilnych jest zazwyczaj długotrwały. Niekiedy jednak sprzyjają mu pewne doraźne wydarzenia, np. spektakularne afery z udziałem rządzących. ${ }^{20}$ Aby wzmocnić intensywność przekonania, że woda mineralna $X$ jest najzdrowsza spośród innych wód mineralnych o nieodróżnialnych od siebie smakach, można na etykiecie umieścić pozytywną opinię utworzonego jedynie w tym celu instytutu o dobrze brzmiącej nazwie.

${ }^{21}$ Według Davidsona sformułowanie zamiaru nie jest obietnicą lub zobowiązaniem - jeśli zmienimy zdanie, to nie złamiemy danego sobie słowa. Oczywiście sytuacja się zmienia jeśli
} 
stały i stabilny, to część naszych przekonań, które biorą istotny udział w formułowaniu zamiaru względnego może się zmieniać pod wpływem bodźców płynących ze środowiska, okoliczności, dostarczonych informacji lub innych zabiegów manipulacyjnych. Fakt ten znany jest specjalistom od sprzedaży bezpośredniej, którzy z reguły nie pozostawiają klientom czasu na zastanowienie. W podobny sposób działają na nas modne ostatnio akcje wyprzedażowe, podczas których sugeruje się, że podana na czerwono cena jest wyjątkowo korzystna i okazja nigdy więcej się już nie powtórzy. W takim przypadku zasadnicze wartości i preferencje sprawcy pozostają niezmienne, lecz o konkluzji sylogizmu praktycznego decydują właśnie owe doraźne, często fałszywe przekonania dostarczone przez manipulatora. Zauważmy, że o ile w pierwszym typie manipulacji, manipulowany zazwyczaj przez dłuższy czas pozytywnie ocenia swoje działania (np. decyzje wyborcze), to w drugim typie manipulacji, manipulowany często bardzo szybko żałuje tego co zrobił. Jest to zrozumiałe, gdyż w obu przypadkach o działaniu decydują zupełnie inne postawy. W pierwszym przypadku są one trwałe i stabilne, a w drugim chwilowe i ulotne.

Przed wprowadzeniem trzeciego typu działania manipulacyjnego musimy powrócić do zasygnalizowanego wcześniej problemu formowania zamiaru działania. Należy bowiem wyjaśnić związek między działaniem polegającym na formowaniu zamiarów działania a działaniem, o ile ono zaszło. Nieco wcześniej była mowa o tym, że powodem działania nie może być inne działanie, a zatem formowanie zamiaru działania nie może być powodem tego działania. Musi zatem istnieć jakaś inna, bardziej złożona zależność, która pozwoli wyjaśnić, że zazwyczaj (choć nie zawsze) realizujemy własne zamiary względne, szczególnie te, które mają być realizowane bezpośrednio po wyciągnięciu odpowiedniej konkluzji w sylogizmie praktycznym ${ }^{22}$. Dlaczego zatem zazwyczaj gdy poweźmiemy zamiar prima facie realizujemy go, chociaż powzięcie zamiaru nie może być powodem działania? Zbieżność tę Davidson wyjaśnia odwołując się do racjonalności istot ludzkich, przywołując trzeci już sposób rozumienia tego pojęcia, por. eseje z trzeciej części [Davidson 2004]. Racjonalność w tym sensie oznacza równoległość dwóch zupełnie rożnych relacji: relacji logicznych między przesłankami a wnioskami w sylogizmie praktycznym oraz relacji przyczynowej między działaniami a ich powodami

sformułowaniu zamiaru prima facie towarzyszy wygłoszenie obietnicy wykonania określonego działania.

${ }^{22}$ Znacznie jest łatwiej realizować zamiary, których realizacja następuje bezpośrednio po ich powzięciu. Trudniej jest realizować zamiary długofalowe, np. prace doktorskie. 
Aby to wyjaśnić odwołajmy się do pewnego przykładu. Podczas oficjalnego spotkania $\mathrm{z}$ okazji jubileuszu kolegi jeden $\mathrm{z}$ uczestników ma o nim powiedzieć kilka słów. Osoba ta nie znosi jubilata, ma o nim bardzo niskie mniemanie i ma wielką chęć, aby dać temu wyraz. Jednak biorąc pod uwagę okoliczności i swoje przewidywania na temat reakcji otoczenia, poczuwa się do obowiązku wygłoszenia o jubilacie kilku ciepłych słów. Biorąc pod uwagę wszystkie swoje postawy (przekonania, wartości, preferencje) formułuje zamiar wygłoszenia przemowy o przygotowanej w tym celu, pozytywnej treści. W sylogizmie praktycznym przeważa zatem postawa poczucia obowiązku wygłoszenia pochwały jubilata, co znajduje wyraz w odpowiednim sądzie względnym. Racjonalność mówcy w trzecim sensie tego słowa polega na tym, że ta sama postawa (a dokładniej jej aktualizacja) staje się powodem (czyli przyczyną) działania polegającego na wygłoszeniu pozytywnej przemowy.

Davidson nie wyjaśnia dlaczego jesteśmy (zazwyczaj) istotami racjonalnymi w tym sensie. Być może da się to wyjaśnić w kategoriach ewolucji, gdyż działania racjonalne, tj. realizowanie powziętych zamiarów, na ogół sprzyjają przeżyciu. Nie sposób jednak - zdaniem Davidsona - wyobrazić sobie sprawcy, który jest konsekwentnie nieracjonalny, gdyż nigdy nie realizowałby przedsięwziętych zamiarów. Byłby on targany wewnętrznymi impulsami całkowicie niezrozumiałymi dla otoczenia, gdyż bardzo często w podobnych okolicznościach ludzie o podobnych postawach formują podobne zamiary względne i często je realizują ${ }^{23}$. W rezultacie nie można by go było nawet uznać za istotę wolną. Nie miałoby również sensu wygłaszanie przez niego jakichkolwiek zamiarów, skoro jego działania nie miałyby z tymi zamiarami żadnego związku i miałyby charakter przypadkowy. Oczywiście w pojedynczych przypadkach możliwe są odstępstwa od tak rozumianej racjonalności działania. Ale o działaniach nieracjonalnych w tym sensie można mówić tylko wtedy, jeśli są one odstępstwami od ogólnej racjonalności sprawcy. Owo odstępstwo od racjonalności (czyli równoległości relacji logicznej i przyczynowej) może być skutkiem trzeciego typu działania manipulacyjnego, który zostanie omówiony w następnym paragrafie.

\section{TRZECI TYP MANIPULACJI A SŁABOŚĆ WOLI}

Typowym przypadkiem nieracjonalności $\mathrm{w}$ trzecim sensie jest tzw. słabość woli. Problem słabości woli, akrazji lub działania niekontrolowanego (incontinent) Davidson rozpatruje jako niezależny od wszelkich rozważań etycznych

\footnotetext{
${ }^{23} \mathrm{Na}$ tym założeniu opierają się dwa omówione w tym paragrafie typy manipulacji.
} 
[Davidson 1969]. Działanie akratyczne polega na tym, że sprawca formułuje zamiar względny (jako wniosek sylogizmu praktycznego ${ }^{24}$, lecz nie podejmuje zamierzonego działania lub podejmuje działanie zupełnie inne od zamierzonego. Problem postawiony przez Davidsona w [1969] streszczony jest w tytułowym „kantowskim” pytaniu: „Jak możliwa jest słabość woli?”, przy założeniu przyczynowej teorii działania. Być może - jak przewrotnie zastanawia się Davidson - w ramach przyczynowej teorii nie da się wyjaśnić fenomenu słabej woli, gdyż działanie akratyczne jest faktycznie działaniem, a zatem jest intencjonalne - nie zatem tylko zdarzeniem, w którym uczestniczymy. Każde działanie intencjonalne posiada jednak powód. Powód ten aktualizowany jest przez pewne zdarzenie mentalne, które jest przyczyną działania akratycznego. A zatem działanie akratycznie zasadniczo się nie różni od działania zamierzonego, gdyż oba mają powody.

Jak pokazuje Davidson przyczynowa teoria działania pozwala jednak na wyjaśnienie jak możliwe jest działanie akratyczne. Wyobraźmy sobie, że bardzo lubię słodycze i w pewnej sytuacji mam wielką ochotę zjeść coś słodkiego. Jednocześnie widzę leżący na stole batonik oraz kwaśne jabłko oraz wiem, że zjedzenie tego batonika jest działaniem polegającym na zjedzeniu czegoś słodkiego. $\mathrm{Z}$ drugiej strony czuję się zobowiązany dbać o zdrowie i wiem, że służy temu powstrzymanie się od zjedzenia batonika. Biorąc to po uwagę formują zamiar powstrzymania się od zjedzenia tego batonika lub zamiar zjedzenia jabłka zamiast batonika. Mimo to biorę batonik i go zjadam, mając jednocześnie głębokie przekonanie, że nie powinienem tego czynić. To co zrobiłem jest oczywiście działaniem, czyli zdarzeniem intencjonalnym, nikt bowiem nie wtłoczył mi batonika do ust. Podany przykład działania akratycznego można wyjaśnić w sposób następujący. Budując sylogizm uwzględniam żywione przeze mnie postawy, czyli wartości (np. zdrowie), preferencje (np. wolę słodycze od owoców), trwałe przekonania (np. słodycze szkodzą zdrowiu) oraz przekonania doraźne zależne od konkretnej sytuacji (np. leżący na stole batonik jest słodki i nie jest zatruty, że nie jestem specjalnie głodny i nie grozi mi w najbliższym czasie zasłabnięcie $\mathrm{z}$ tego powodu itp.). Biorąc to wszystko pod uwagę formuję zamiar względny zjedzenia jabłka. Jednak w przypadku działania akratycznego zjadam batonik i czynię to intencjonalnie. Oznacza to, że w przypadku działania, które przeprowadziłem, miałem zamiar bezwzględny, aby je przeprowadzić, gdyż każde działanie jest zamierzone. W związku z tym Davidson zadaje następujące pytanie:

\footnotetext{
${ }^{24}$ Pojęcie sylogizmu praktycznego pochodzi od Arystotelesa. W [1969] Davidson modyfikuje oryginalną postać sylogizmu praktycznego
} 
Jak jest możliwe, aby ktoś uważał, że $a$ jest lepsze od $b$, uwzględniając wszelkie okoliczności, lecz jednocześnie nie uważał, że $a$ jest lepsze od $b$ ? [Davidson 1980(1969), s. 39]

Davidson nie widzi w tym żadnej sprzeczności, gdyż ta sama sieć żywionych postaw może być przyczyną działania różnego od działania (jedynie) zamierzonego względnie. W takim przypadku zamiar bezwzględny może być wyjaśniony przez odwołanie się do powodu przeprowadzonego działania. W przypadku zjedzenia batonika powód tego działania można opisać jako chęć zjedzenia czegoś słodkiego i przekonania, że zjedzenie batonika jest działaniem tego typu ${ }^{25}$. Upraszczając nieco zagadnienie można powiedzieć, że w przypadku akrazji została zaburzona równoległość relacji logicznej oraz relacji przyczynowej. Relacja logiczna ${ }^{26}$ zachodzi między uświadomionymi przez sprawcę postawami a zamiarem względnym (konkluzją w sylogizmie praktycznym), zaś relacja przyczynowa - między działaniem a jego powodem. Rozbieżność ta jest rezultatem tego, że pewne postawy przeważają jako przesłanki sylogizmu praktycznego (np. uznanie, że warto zachować zdrowie), ale inne postawy przejawiają większą moc przyczynową (np. chęć zjedzenia batonika). Oznacza to, że w przypadku akrazji rozum praktyczny nie kontroluje naszego działania, co oznacza nieracjonalność w trzecim z wyróżnionych sensów.

To uproszczone nieco w stosunku do przedstawionego przez Davidsona wyjaśnienia fenomenu słabej woli pozwala zrozumieć trzeci rodzaj manipulacji. Manipulacja w tym sensie polega na takim oddziaływaniu przyczynowym, aby nie zmieniając układu przekonań (nawet tych doraźnych) zwiększyć moc przyczynową pewnych postaw. Do zabiegów manipulacyjnych tego typu należy hipnoza, reklama podprogowa oraz różne reklamy, które odwołują się do słabej woli, np. „Daj sobie chwilę przyjemności”. Do manipulacji tego typu zdolne są również osoby bardzo sugestywne potrafiące skłonić innych do działań niezgodnych z ich zamiarami względnymi. Czasami działanie manipulacyjne tego typu polega na odpowiednim oddziaływaniu obrazem, a niekiedy zapachem, co ma wzmocnić moc przyczynową pewnych postaw, które nie odgrywają zasadniczej roli w sylogizmie praktycznym.

\footnotetext{
${ }^{25}$ Działanie akratyczne jest świadomym działaniem - nie polega zatem na zdarzeniu, w którym uczestniczymy w sposób nieświadomy i całkowicie niezamierzony. Zjedzenie batonika wbrew sformułowanemu w sylogizmie praktycznym zamiarowi względnemu powstrzymania się od tego działania, nie jest aktem ,dzikiego zachowania”, które mogłoby świadczyć, że sprawca jest nieświadomy tego, co się z nim dzieje, lecz może przybrać bardzo wyrafinowana postać.

${ }^{26}$ Nie musi to być jednak relacja wynikania logicznego.
} 
Działanie akratyczne, np. polegające na zakupie wbrew formułowanemu zamiarowi względnemu zbędnego produktu lub usługi, jest racjonalne w pierwszym $\mathrm{z}$ wymienionych sensów (bo jest działaniem, a zatem ma powód), jest nieracjonalne w drugim, ocennym sensie (bo jego skutki nie są zgodne $\mathrm{z}$ interesem manipulowanego) $\mathrm{i}$ jest nieracjonalne $\mathrm{w}$ trzecim sensie (bo jest działaniem akratycznym). O tym, że oddziaływanie na sprawcę ma charakter manipulacyjny decyduje drugi rodzaj nieracjonalności działania. Oczywiście nie każde działanie podmiotu, które wywołuje u kogoś innego działanie akratyczne jest $\mathrm{z}$ definicji manipulacją $\mathrm{w}$ tym sensie, gdyż w niektórych przypadkach jego skutki mogą być faktycznie dla sprawcy korzystne, a zatem zgodne $\mathrm{z}$ jego najlepszym interesem, np. w przypadku terapii lub resocjalizacji.

\section{UWAGI KOŃCOWE}

Celem artykułu było zastosowanie aparatury pojęciowej przyczynowej teorii działania do analizy zabiegów manipulacyjnych i wyodrębnienie trzech typów takich zabiegów. Przez manipulację rozumie się takie przyczynowe oddziaływanie na sprawcę, w rezultacie którego podejmuje działania o niekorzystnych dla siebie skutkach ${ }^{27}$. Dwa pierwsze typy działań manipulacyjnych polegają na takim oddziaływaniu na sprawcę, aby zmodyfikować jego układ (sieć) postaw propozycjonalnych. W rezultacie sprawca formułuje zamiar działania zgodny $\mathrm{z}$ interesem manipulatora, a następnie zamierzone działania podejmuje lub przynajmniej formuje zamiar ich podjęcia. W pierwszym typie mamy do czynienia $\mathrm{z}$ oddziaływaniem na $\mathrm{w}$ miarę stałe postawy, zaś w typie drugim na postawy doraźne, czyli te które związane są z szeroko rozumianym kontekstem, w którym odbywa się manipulacja. Można zatem powiedzieć, że drugi typ działań manipulacyjnych polega głównie na wywoływaniu u sprawcy fałszywego obrazu zmiennych aspektów rzeczywistości, czyli oszukiwaniu go. Trzeci typ polega na takim oddziaływaniu na sprawcę, aby skłonić go do działania akratycznego, tj. niezgodnego ze sformułowanym zamiarem względ-

\footnotetext{
${ }^{27}$ Takie postawienie sprawy nie rozwiązuje wszystkich problemów związanym z oddzieleniem manipulacji od innych zabiegów wpływających na ludzkie działania, gdyż nie istnieją obiektywne kryteria tego, czy konsekwencje działań sprawcy są dla niego korzystne. Jest to uwikłane $\mathrm{w}$ postawy dominujące $\mathrm{w}$ danym społeczeństwie, np. poglądy religijne. Nie bez znaczenia są również intencje manipulatora oraz jego szczerość związana z nieukrywaniem lub ukrywaniem zamiarów. Ponadto pewne działania mogą być korzystne doraźnie, lecz niekorzystne na dłuższą metę. Problem odróżnienia manipulacji od innych zabiegów jest jednak w moich rozważaniach problemem pobocznym.
} 
nym, a zatem bez modyfikacji jego układu postaw, nawet tych zmiennych i doraźnych.

Jak łatwo zauważyć nie może tu być mowy o ścisłym podziale zabiegów manipulacyjnych, lecz raczej o ich typach, gdyż granice między nimi są nieostre. Jest to konsekwencja oczywistego faktu, że nie ma ostrej granicy między postawami stałymi a doraźnymi. Ponadto sytuacja, w której można oddziaływać przyczynowo na sprawcę bez jakiejkolwiek modyfikacji, choćby doraźnej, pewnych postaw propozycjonalnych, jest sytuacją skrajnie wyidealizowaną. W rezultacie granice między pierwszym a drugim typem działań manipulacyjnych oraz typem drugim a trzecim są zatarte. Mimo to uważam, że proponowany tutaj aparat teoretyczny może rzucić ciekawe światło na badania poświęcone zabiegom manipulacyjnym i dostarczyć cennych narzędzi do przeciwdziałania tym zabiegom.

Za zakończenie warto ponownie przywołać bardzo optymistyczny aspekt przyczynowej teorii działania Davidsona. Pomimo niewątpliwego doskonalenia technik manipulacyjnych, techniki te nigdy nie staną się absolutnie skuteczne, gdyż niemożliwe jest istnienie „praw” manipulowania innymi ludźmi, którzy nawet będąc manipulowanymi, pozostają wolni i mogą się owej manipulacji przeciwstawić. W związku z tym pozostaje jeszcze do rozważenia problem odpowiedzialności za działania, zarówno za manipulowanego, jaki i działania manipulatora. Osoba manipulowana podejmuje działania, a zatem ponosi za nie odpowiedzialność. Oczywiście fakt bycia manipulowanym może stanowić okoliczność łagodzącą, ale całkowicie od odpowiedzialności nas nie zwalnia. Jak można jednak wyjaśnić odpowiedzialność manipulatora za działania manipulowanego?

Przypomnijmy, że każde działanie może być nazywane na wiele sposobów, również ze względu na skutki owych działan. W artykule Agency [1971] Davidson argumentuje, że łańcuch skutków, które mogą posłużyć do nazywania działań kończy się tam, gdzie pojawia się inne działanie. Wyraża to oczywistą intuicję, że działanie manipulowanego nie jest działaniem manipulatora. A zatem sprawstwo (agency) kończy się tam, gdzie pojawia się inne działanie. Koniec sprawstwa nie wyklucza jednak odpowiedzialności za skutki działań, które są jedynie skutkami działań, nie zaś działaniami sprawcy. Podobnie jest również w przypadku innych działań, za które jesteśmy odpowiedzialni nie tylko ze względu na intencje, ale nawet za niezamierzone skutki. 


\section{BIBLIOGRAFIA}

Davidson, D. (1963), Actions, Reason, and Causes. „The Journal of Philosophy” 60, s. 685-701. Przedruk [w:] Davidson 1980, s. 3-19.

Davidson, D. (1969), How is Weakness of the Will Possible?, [w:] J. Feiberg (ed.) Moral Concepts. „Oxford Readings in Philosophy”, Oxford University Press. Przedruk [w:] Davidson 1980, s. 21-42. Tłumaczenie polskie: Jak jest możliwa słabość woli, tłum. W. J. Popowski, [w:] J. Hołówka (red.) Filozofia moralności. Warszawa, Wydawnictwo Spacja, 1997, s. 81-106.

Davidson, D. (1971), Agency, [w:] R. Binkley, R. Bronaugh i A. Marras (eds.) Agent, Action, and Reason. University of Toronto Press. Przedruk [w:] Davidson 1980, s. 43-61.

Davidson, D. (1978), Intending, [w:] Y. Yovel (red.) Philosophy of History and Action. Reidel and The Magnes Press, The Hebrew University. Przedruk [w:] Davidson 1980, s. 83-102.

Davidson, D. (1980), Essays on Actions and Events. Clerendon Press.

Davidon, D. (2004), Problems of Rationality. Clerendon Press.

Van Dijk, T. A. (2006), Discourse and Manipulation. „Discourse and Society”, 17, s. 359-383.

Zaltman, G., Zaltman, L. M. (2008), Marketing Metaphoria. Why Deep Metaphors Reveal About the Minds of Consumers. Harvard Business School Press.

\section{THREE TYPES OF MANIPULATION FROM THE POINT OF VIEW THEORY OF ACTION}

(Abstract)

By manipulation one can understand an abuse of the influence on other people. As the term 'abuse' is vague and unclear, one cannot decide in every instance whether it is an abuse of influence or whether the influence on other people is justified. In the paper I distinguish three types of actions consisting in exercising influence on other people. The theoretical basis for this typology is Donald Davidson's theory of action, and in particular his notion of reason of action and practical syllogism. The first type of influence consists in modification of rather constant beliefs, preferences, and values. The typical example of an action of this type is brain-washing, The second type of action is modification of short-term attitudes, e.g. beliefs about the environment, wishes and preferences in special situations, etc. The typical example is advertising. In the third type the manipulator does not try to modify attitudes but he intends to provoke acratic actions, i.e. actions being the result of week will. The typology permits, at least partially, to precise what the abuse consists in for every type of influence.

\section{KEYWORDS}

Action, agent, causality, intention, manipulation, practical syllogism, propositional attitude, reason. 